\title{
Chemical evaluation of proximate, vitamin and amino acid profile of leaf, stem bark and root of indigofera tinctoria
}

\author{
Alagbe, J.O \\ Department of Animal Nutrition and Biochemistry, \\ Sumitra Research Institute, Gujarat, India \\ demsonfarms@yahoo.com
}

\begin{abstract}
Medicinal plants contain substances with high therapeutic value because they contain multiple bioactive chemicals. Chemical analysis of Indigofera tinctoria leaves, stem bark and roots was evaluated. The result revealed that proximate composition of Indigofera tinctoria leaves contained $12.49 \%$ moisture content (M.C), $87.51 \%$ dry matter (DM), $30.53 \%$ crude protein (CP), $19.02 \%$ crude fibre $(C F), 2.44 \%$ ether extract (EE), $13.86 \%$ ash, $36.59 \%$ carbohydrate $(C H O)$ and $254.1 \mathrm{kcal} / 100 \mathrm{~g}$ energy (ME). Indigofera tinctoria stem bark contained M.C (6.40 \%), DM (93.60\%), CP (5.11\%), CF (54.49\%), EE (2.00\%), ash (10.42\%), CHO $(29.98 \%)$ and $M E(156.0 \mathrm{kcal} / 100 \mathrm{~g})$. Indigofera tinctoria roots contained $M C, D M, C P, C F, E E$, ash, CHO and ME at $10.04 \%, 89.60 \%, 8.22 \%, 40.88 \%, 1.21 \%, 8.43 \%, 42.47 \%$ and $210.0 \mathrm{kcal} / 100 \mathrm{~g}$ respectively. Vitamin analysis showed that Indigofera tinctoria leaves, stem bark and roots contained $\beta$-carotene (8.45, 2.88 and 5.11 $\mathrm{mg} / 100 \mathrm{~g})$, Vitamin $B 1$ (1.94, 0.33 and $1.00 \mathrm{mg} / 100 \mathrm{~g})$, Vitamin B2 (0.71, 0.21 and $0.50 \mathrm{mg} / 100 \mathrm{~g})$, Vitamin B3 (0.66, 0.34 and $0.48 \mathrm{mg} / 100 \mathrm{~g})$, Vitamin B6 (0.32, 0.21 and $0.30 \mathrm{mg} / 100 \mathrm{~g})$, Vitamin B7 (0.63, 0.01 and 0.16 $\mathrm{mg} / 100 \mathrm{~g})$, Vitamin $B 9(0.26,0.10$ and $0.18 \mathrm{mg} / 100 \mathrm{~g})$, Vitamin B12 (0.21, 0.03 and $0.10 \mathrm{mg} / 100 \mathrm{~g})$, Vitamin C (14.0, 3.56 and $9.44 \mathrm{mg} / 100 \mathrm{~g})$, Vitamin $\mathrm{D}(0.10,0.01$ and $0.06 \mathrm{mg} / 100 \mathrm{~g})$ and Vitamin $\mathrm{K}(0.17,0.07$ and 0.12 $\mathrm{mg} / 100 \mathrm{~g}$ ). Amino acid analysis revealed the presence of threonine, leucine, lysine, valine, tryptophan, glycine, phenylalanine, histidine, methionine, alanine, serine, proline, aspartate, glutamic acid, tryrosine and cysteine in Indigofera tinctoria leaves, stem bark and roots at (7.65 \%, 1.22 \% and 3.03\%), (5.76, $1.09 \%$ and $2.46 \%),(3.11$ $\%, 1.21 \%$ and $2.00 \%),(7.21 \%, 3.53 \%$ and $4.09 \%),(1.45 \%, 0.03 \%$ and $1.00 \%),(4.76 \%, 0.08 \%$ and $2.33 \%)$, $(6.33 \%, 2.45 \%$ and $3.49 \%),(7.42 \%, 2.00 \%$ and $3.00 \%),(3.49 \%, 0.01 \%$ and $2.00 \%),(2.41 \%, 0.56 \%$ and $1.20 \%),(5.23 \%, 1.22 \%$ and $1.76 \%),(2.87 \%, 0.57 \%$ and $1.00 \%),(5.32 \%, 2.11 \%$ and $3.56 \%),(9.66 \%, 4.21$ $\%$ and $5.11 \%),(2.45 \%, 0.57 \%$ and $1.67 \%)$ and $(1.85 \%, 0.81 \%$ and $0.89 \%)$ respectively. It was concluded that Indigofera tinctoria leaves, stem bark and roots are loaded with significant quantity of nutrients, vitamins and amino acid (leaves $>$ roots $>$ stem bark).
\end{abstract}

Keywords: Indigofera tinctoria; amino acids; proteins; vitamins

\section{Introduction}

Natural plant product remedies are popularly preferred as they are widely available, economically viable, and environmentally friendly with fewer side effects (Upadhyay, 2011; Olafadehan et al., 2020). A wide range of medicinal plant parts are targeted for extraction, including leaves, roots, flowers, fruits, twigs and exudates (Uniyal et al., 2006; Makhosazana, 2015). The extraction solubizes secondary metabolites in the form of several of such polyphenols as tannins, phenols, terpenoids, flavornoids, saponins and steroids that have complex structures involving many chiral centers that determine their biological activity (Bruneton, 1995; Olafadehan et al., 2020; Alagbe, 2019). Alagbe et al. (2020) reported that there are over 250,000 species of medicinal plant out of which WHO (2010) enlisted 21,000 medicinal plant species. Among some of the underexplored medicinal plant is Indigofera tinctoria.

Indigofera tinctoria Linn is a leguminous plant belonging to the family fabaceae which is ranked the third largest family of the blossoming plants after Orchidnaceae and Asteraceae with approximately 650 genera and 1800 different species (Mohammad et al., 2018; Alagbe and Omokore, 2019). It is wide spread across tropical regions around the world and had been cultivated and highly valued for centuries as the main source of indigo dye, leading to its common name "true indigo". It grows to about 2.5 meters with short, green imaripinnate leaflets, flowers are about 6-10 $\mathrm{mm}$ in auxillary racemes and characterized by bright red or rosy colour (Shinwari et al., 2006).

Phytochemical screening of Indigofera tinctoria reveals the presence of several bioactive chemicals or phytochemicals (tannins, saponins, phenols, flavonoids, terpenoids, alkaloids, steroids etc.), minerals (calcium, phosphorus, potassium, iron, zinc, magnesium, selenium, sodium, copper, manganese, cobalt, molybdenum etc.), vitamins and fatty acids (Yinusa et al., 2007; Bueno et al., 2013; Chakrabarti et al., 2006). Phytochemical constituents performs several pharmacological effects in animals effect such as antibacterial, antifungal, antiviral, anti-inflammatory, hypolipidemic, neuroprotective, anti-allergic, hepato-protective, antipasmodic and antioxidants (Prakash et al., 2007; Shahjahan et al., 2005; Oluwafemi et al., 2020). The plants (leaf, stem bark and roots) have also traditionally been used for the treatment of toothache, abdominal pain, waist pain, piles, epistaxis, 
rheumatism, stroke and sexually transmitted diseases (Esimon et al., 1999; Abubakar et al., 2006).

In view of these abundant potentials, Indigofera tinctoria could be used as an alternative to synthetic antibiotics in animal feed, reduce cost of production and mortality as well as promote food safety and eliminate worrying cases of antibiotic residues in animal products and dangers posed to human health. This experiment was designed to examine the proximate, vitamin and amino acid profile of leaf, stem bark and root of Indigofera tinctoria.

\section{MATERIALS AND METHODS}

\section{Study Area}

The experiment was carried out at Division of Animal Nutrition, Sumitra Research Institute, Gujarat, India during the month of April to June, 2019.

Sources, collection and preparation of test materials

Fresh leaves, stems and roots of Indigofera tinctoria were collected from a local market in Gujarat, India. The plants were authenticated by a plant taxonomist (Dr. Chen Xung). The collected leaves, root and stem bark of Indigofera tinctoria were cut separately into pieces, washed with running tap water to remove all dirty particles and oven dried separately at $60^{\circ} \mathrm{C}$ for 24 hours, it was later removed and grinded into fine powder using mortar and pestle, sieved and stored separately in a labeled air tight container and kept for further analysis.

\section{Parameters measured}

Proximate compositions of the plant samples were determined by using the Official Methods of the Association of Official Analytical Chemist (AOAC, 2000).

Total carbohydrate was determined according the method of James (1995) using the equation below:

Total carbohydrate $=100-(\%$ crude protein $+\%$ crude fibre $+\%$ ash $)$

Dry matter $(\mathrm{DM})=100-$ moisture content

Energy value (kcal/100 g) was determined using the formula described by Crisan and Sands (1978) as follows:

Energy $(\mathrm{kcal} / 100 \mathrm{~g})=(2.62 \times \%$ crude protein $)+(8.37 \times \%$ ether extract $)+(4.2 \times$ total carbohydrate $)$

Amino acid analyses were carried out using Ion Exchange Chromatographic Method (IECM) model (9B FB- 01F) and other methods outlined by Olafadehan et al. (2020).

Vitamin analyses were carried out according to methods outlined by Ngozi at al. (2017) and Onwuka (2005).

\section{Statistical analysis}

The analyses were done in triplicates and the data obtained were expressed as mean \pm standard error of the means (mean \pm S.E.M). The data were subjected to one way analysis of variance (ANOVA) and differences between samples were determined Duncan multiple range test (Duncan, 1955). Significant was declared if $P \leq 0.05$.

Table 1 Proximate composition of Indigofera tinctoria leaf, stem bark and root

\begin{tabular}{lccc}
\hline Parameters & Leaf & Stem bark & Root \\
\hline Moisture (\%) & $12.49 \pm 0.36^{\mathrm{a}}$ & $6.40 \pm 0.02^{\mathrm{b}}$ & $10.04 \pm 0.40^{\mathrm{a}}$ \\
Dry matter & $87.51 \pm 0.01$ & $93.60 \pm 0.17$ & $89.60 \pm 0.05$ \\
Crude protein (\%) & $30.53 \pm 0.07^{\mathrm{a}}$ & $5.11 \pm 0.02^{\mathrm{c}}$ & $8.22 \pm 0.01^{\mathrm{b}}$ \\
Crude fibre (\%) & $19.02 \pm 0.10^{\mathrm{c}}$ & $54.49 \pm 0.25^{\mathrm{a}}$ & $40.88 \pm 0.59^{\mathrm{b}}$ \\
Ether extract (\%) & $2.44 \pm 0.00$ & $2.00 \pm 0.01$ & $1.21 \pm 0.00$ \\
Ash (\%) & $13.86 \pm 0.08^{\mathrm{a}}$ & $10.42 \pm 0.05^{\mathrm{a}}$ & $8.43 \pm 0.02^{\mathrm{b}}$ \\
Total carbohydrate (\%) & $36.59 \pm 0.03^{\mathrm{a}}$ & $29.98 \pm 0.01^{\mathrm{b}}$ & $42.47 \pm 0.02^{\mathrm{a}}$ \\
Energy (kcal/100g) & $254.1 \pm 0.00$ & $156.0 \pm 0.00$ & $210.0 \pm 0.00$ \\
\hline
\end{tabular}

Values expressed as mean \pm SEM $(n=3)$

Means in the same row with different superscripts differ significantly $(P<0.05)$

Table 2 Vitamin composition of Indigofera tinctoria leaf, stem bark and root

\begin{tabular}{lccc}
\hline Parameters (mg/100 g) & Leaf & Stem bark & Root \\
\hline B- carotene & $8.45 \pm 0.44^{\mathrm{a}}$ & $2.88 \pm 0.03^{\mathrm{b}}$ & $5.11 \pm 0.13^{\mathrm{a}}$ \\
Vitamin B1 (Thiamine) & $1.94 \pm 0.00^{\mathrm{a}}$ & $0.33 \pm 0.01^{\mathrm{b}}$ & $1.00 \pm 0.00^{\mathrm{a}}$ \\
Vitamin B2 (Riboflavin) & $0.71 \pm 0.01$ & $0.21 \pm 0.00$ & $0.50 \pm 0.01$ \\
Vitamin B3 (Niacin) & $0.66 \pm 0.02$ & $0.34 \pm 0.01$ & $0.48 \pm 0.10$ \\
Vitamin B6 (Pyridoxine) & $0.32 \pm 0.00$ & $0.21 \pm 0.01$ & $0.30 \pm 0.00$ \\
\hline
\end{tabular}




\begin{tabular}{llll}
\hline Vitamin B7 (Biotin) & $0.63 \pm 0.01^{\mathrm{a}}$ & $0.01 \pm 0.00^{\mathrm{c}}$ & $0.16 \pm 0.01^{\mathrm{b}}$ \\
Vitamin B9 (Folic acid) & $0.26 \pm 0.04^{\mathrm{a}}$ & $0.10 \pm 0.00^{\mathrm{b}}$ & $0.18 \pm 0.00^{\mathrm{b}}$ \\
Vitamin B12 (Cyanocobalamin) & $0.21 \pm 0.00^{\mathrm{a}}$ & $0.03 \pm 0.01^{\mathrm{b}}$ & $0.10 \pm 0.00^{\mathrm{a}}$ \\
Vitamin C (Ascorbic acid) & $14.0 \pm 1.22^{\mathrm{a}}$ & $3.56 \pm 0.02^{\mathrm{c}}$ & $9.44 \pm 1.04^{\mathrm{b}}$ \\
Vitamin D (Calciferol) & $0.10 \pm 0.01$ & $0.01 \pm 0.00$ & $0.06 \pm 0.01$ \\
Vitamin K (Phytonadione) & $0.17 \pm 0.00$ & $0.07 \pm 0.00$ & $0.12 \pm 0.00$ \\
\hline
\end{tabular}

Values expressed as mean $\pm \operatorname{SEM}(\mathrm{n}=3)$

Means in the same row with different superscripts differ significantly $(P<0.05)$

Table 3 Amino acid composition of Indigofera tinctoria leaf, stem bark and root

\begin{tabular}{llll}
\hline Parameters (\%) & Leaf & Stem bark & Root \\
\hline Essential amino acid & & & $3.03 \pm 0.00^{\mathrm{b}}$ \\
Threonine & $7.65 \pm 0.98^{\mathrm{a}}$ & $1.22 \pm 0.01^{\mathrm{c}}$ & $2.46 \pm 0.01^{\mathrm{a}}$ \\
Leucine & $5.76 \pm 0.02^{\mathrm{a}}$ & $1.09 \pm 0.00^{\mathrm{b}}$ & $2.00 \pm 0.00$ \\
Lysine & $3.11 \pm 0.01$ & $1.21 \pm 0.01$ & $4.09 \pm 0.02^{\mathrm{b}}$ \\
Valine & $7.21 \pm 1.56^{\mathrm{a}}$ & $3.53 \pm 0.00^{\mathrm{c}}$ & $1.00 \pm 0.00$ \\
Tryptophan & $1.45 \pm 0.03$ & $0.03 \pm 0.00$ & $2.33 \pm 0.10$ \\
Glycine & $4.76 \pm 0.02$ & $0.08 \pm 0.00$ & $3.49 \pm 0.08^{\mathrm{b}}$ \\
Phenylalanine & $6.33 \pm 0.01^{\mathrm{a}}$ & $2.45 \pm 0.10^{\mathrm{b}}$ & $3.00 \pm 0.02^{\mathrm{b}}$ \\
Histidine & $7.42 \pm 0.04^{\mathrm{a}}$ & $2.00 \pm 0.00^{\mathrm{b}}$ & $2.00 \pm 0.01^{\mathrm{b}}$ \\
Methionine & $3.94 \pm 0.00^{\mathrm{a}}$ & $0.01 \pm 0.00^{\mathrm{c}}$ & \\
& & & $1.20 \pm 0.00$ \\
Non-essential amino acid & & & $1.76 \pm 0.00^{\mathrm{b}}$ \\
Alanine & $2.41 \pm 0.10$ & $0.56 \pm 0.02$ & $1.00 \pm 0.01$ \\
Serine & $5.23 \pm 0.14^{\mathrm{a}}$ & $1.22 \pm 0.00^{\mathrm{b}}$ & $3.56 \pm 0.03^{\mathrm{b}}$ \\
Proline & $2.87 \pm 0.02$ & $0.57 \pm 0.01$ & $5.11 \pm 1.00^{\mathrm{b}}$ \\
Aspartic acid & $5.32 \pm 0.00^{\mathrm{a}}$ & $2.11 \pm 0.00^{\mathrm{b}}$ & $1.67 \pm 0.06$ \\
Glutamic acid & $9.66 \pm 1.00^{\mathrm{a}}$ & $4.21 \pm 0.01^{\mathrm{b}}$ & $0.89 \pm 0.03$ \\
Tyrosine & $2.45 \pm 0.01$ & $0.57 \pm 0.00$ & $0.81 \pm 0.00$ \\
Cysteine & $1.85 \pm 0.00$ & & \\
\hline Values expressen
\end{tabular}

Values expressed as mean \pm SEM $(n=3)$

Means in the same row with different superscripts differ significantly $(P<0.05)$

\section{Result and discussion}

\section{Proximate composition of Indigofera tinctoria leaf, stem bark and root}

Table 1 reveals the proximate composition of Indigofera tinctoria leaf, stem bark and root. Indigofera tinctoria leaf, stem bark and root contained moisture $(12.49 \%, 6.40 \%$ and $10.04 \%)$, dry matter $(85.71 \%, 93.60$ $\%$ and $89.60 \%)$, crude protein $(30.53 \%, 5.11 \%$ and $8.22 \%)$, crude fibre $(19.02 \%, 54.49 \%$ and $40.88 \%)$, ether extract $(2.44 \%, 2.00 \%$ and $1.21 \%)$, ash $(13.86 \%, 10.42 \%$ and $8.43 \%)$, total carbohydrate $(30.59 \%, 29.98 \%$ and $42.47 \%$ ) and energy $(254.1,156.0$ and $210.0 \mathrm{kcal} / 100 \mathrm{~g})$ respectively. The moisture content in the sample is lower than the values reported for Carpolobia lutea and Piiostigma thonningii leaf (8.84\% and 7.11\%), root (9.55 $\%$ and $8.34 \%$ ) respectively by Olayinka et al. (2019) and Alagbe, J.O (2019). Dry matter value obtained in the test material is lower than values for Desmodium triflorum (33.46\%), Clitoria ternatea (18.61\%), Stylosanthes guianensis (27.06 \%), Calapogonium mucunoides (29.18\%), Albizia falcate (35.46\%), Centrosema pubescens $(33.11 \%)$, Leucaena leucocephala $(32.59 \%)$, Indigofera zollingeriana (25.61\%) and Arachis pintoi leaves (30.66 $\%$ ) but in agreement with the findings of Alagbe et al. (2020) who reported a dry matter of $93.75 \%$ in Daniellia oliveri stem bark. Dry matter is an indicator of the quantity of nutrients that are available to the animal in a particular feed or sample. Crude protein (CP), crude fibre (CF) and ash values in sample was higher than those reported for Eugenia uniflora leaves $(9.58 \%, 1.27 \%$ and $9.24 \%)$, stem $(6.21 \%, 0.67 \%$ and $3.57 \%)$ and root $(7.23 \%, 0.33 \%$ and $7.00 \%)$ reported by Okoh et al. (2011).Higher CF in stem bark and roots of Indigofera tinctoria is an indication that the plant has the ability to

lower 
blood sugar and cholesterol level as well as improving digestion in animals (NHWC, 2002). Leaf of Indigofera tinctoria is rich in protein and could be used as a protein supplement in poultry feed (Atteh, 2000; Alagbe, 2019). The ether extract value obtained in this experiment is lower than those reported for Moringa olifera leaves $(0.40$ $\%)$, stem bark $(0.15 \%)$ and roots $(2.28 \%)$ respectively reported by Olorunfemi et al. (2013). Ash content is a parameter used to access the mineral content in a sample (Onwuka, 2005; Alagbe, 2019). The result revealed that Indigofera tinctoria leaf contained appreciable amount of minerals followed by its stem bark and root respectively. Minerals are spark plug of life necessary for enzyme activation in the body (Gupta et al., 2014).The presence of minerals in livestock feed is important for the animals metabolic processes and its disturbance could lead to deficiencies or variety of diseases (Soetan et al., 2010). According to Aiyesanmi and Oguntokun (1996) fats are essential in diets for energy, structural and biological functioning of cells in the body. Total carbohydrates $(\mathrm{CHO})$ and energy analysis result showed that the leaves of Indigofera tinctoria $>$ roots $>$ stem bark. The value obtained is lower than the values reported for Mangifera indica leaves 60.61\% (CHO); 346.14 (kcal/100g), Persea americana leaves 66.04\% (CHO); $370.47(\mathrm{kcal} / 100 \mathrm{~g})$ and Annona muricata leaves $65.56 \%(\mathrm{CHO}) ; 352.02(\mathrm{kcal} /$ $100 \mathrm{~g}$ ) as reported by Princewill et al. (2019). The result revealed that the test material is lower in energy and thus, it cannot be used as an energy source in livestock feed.

\section{Vitamin composition of Indigofera tinctoria leaf, stem bark and root}

Table 2 reveals the vitamin composition of Indigofera tinctoria leaf, stem bark and root. The sample contained $\beta$ - carotene at $8.45 \mathrm{mg} / 100 \mathrm{~g}, 2.88 \mathrm{mg} / 100 \mathrm{~g}$ and $5.11 \mathrm{mg} / 100 \mathrm{~g}$, vitamin B1 (1.94 mg/100g, 0.33 $\mathrm{mg} / 100 \mathrm{~g}$ and $1.00 \mathrm{mg} / 100 \mathrm{~g})$, vitamin B2 $(0.71 \mathrm{mg} / 100 \mathrm{~g}, 0.21 \mathrm{mg} / 100 \mathrm{~g}$ and $0.50 \mathrm{mg} / 100 \mathrm{~g})$, vitamin B3 (0.66 $\mathrm{mg} / 100 \mathrm{~g}, 0.34 \mathrm{mg} / 100 \mathrm{~g}$ and $0.48 \mathrm{mg} / 100 \mathrm{~g})$, vitamin B6 $(0.32 \mathrm{mg} / 100 \mathrm{~g}, 0.21 \mathrm{mg} / 100 \mathrm{~g}$ and $0.30 \mathrm{mg} / 100 \mathrm{~g}$, vitamin B7 $(0.63 \mathrm{mg} / 100 \mathrm{~g}, 0.01 \mathrm{mg} / 100 \mathrm{~g}$ and $0.16 \mathrm{mg} / 100 \mathrm{~g})$, vitamin $\mathrm{B} 9(0.26 \mathrm{mg} / 100 \mathrm{~g}, 0.10 \mathrm{mg} / 100 \mathrm{~g}$ and 0.18 $\mathrm{mg} / 100 \mathrm{~g})$, vitamin B12 (0.21 mg/100g, $0.03 \mathrm{mg} / 100 \mathrm{~g}$ and $0.10 \mathrm{mg} / 100 \mathrm{~g})$, vitamin $\mathrm{C}(14.0 \mathrm{mg} / 100 \mathrm{~g}, 3.56$ $\mathrm{mg} / 100 \mathrm{~g}$ and $9.44 \mathrm{mg} / 100 \mathrm{~g})$, vitamin $\mathrm{D}(0.10 \mathrm{mg} / 100 \mathrm{~g}, 0.01 \mathrm{mg} / 100 \mathrm{~g}$ and $0.06 \mathrm{mg} / 100 \mathrm{~g})$ and vitamin $\mathrm{K}(0.17$ $\mathrm{mg} / 100 \mathrm{~g}, 0.07 \mathrm{mg} / 100 \mathrm{~g}$ and $0.12 \mathrm{mg} / 100 \mathrm{~g}$ ) for Indigofera tinctoria leaf, stem bark and root respectively. The result revealed that Indigofera tinctoria leaf contained significant quantity of vitamins followed by roots and stem bark. Vitamins are chemically complex organic compounds that have significant role in growth and development of the human body (Muhammad et al., 2017).Vitamin A, E, K and D are fat soluble vitamins whereas, vitamin B1, B2, B3, B6, B7, B9, B12, biotic and vitamin C are water soluble vitamins. $\beta$-carotene are precussors of vitamin A and it plays a key role in good sight or vision as well as cell growth and development (Shearer et al., 2012, 2014; Mata-Granados et al., 2010). According to Jolliffe et al. (2013), vitamin D is important for normal body functioning as its deficiency cause the malformation and softening of bones. Vitamin E protects the membrane fats from oxidative damage and maintains the cellular functioning of the body (Muhammad et al., 2017). Vitamin $\mathrm{K}$ plays a vital role photosynthesis, antioxidants and energy generation by electron movement (Kurosu and Begari, 2010). Vitamin B1 is responsible for the proper functioning of the brain, digestive system, heart and central nervous system (Ba, 2008).Vitamin B2 promotes iron metabolism for the production of red blood cell (Lanska, 2010). According to Combs (2007), vitamin B3 has the ability to scavenge free radicals and protect the tissues from oxidative damage. Vitamin B6 is very important vitamin as it is involved in red blood cell production, carbohydrate metabolism, liver detoxification, brain and nervous system health (Combs, 2007; WHFoods, 2017). Biotin plays a key role in sugar and fat metabolism (WHFoods, 2017). Folic acid (Vitamin B9) regulates the homocysteine level in blood and this amino acid is marker for cardiovascular diseases (McDowell, 2012; Crider et al., 2011). Vitamin B12 vitamin also plays important role in energy metabolism and other biological processes (Asensi et al., 2010; Hayden and Tyagi, 2004). Vitamin C is a strong antioxidant giving full protection to the body and also capable of protecting the lens of eyes, molecules circulating in bloodstream genetic material (DNA) from harmful effects of free radicals (Youdim et al., 2000; Mata-Granados et al., 2010). Vitamin D is essential in calcium absorption in the blood (Faurschou et al., 2012; Jolliffe et al., 2013; Belenchia et al., 2013). Vitamin E exerts positive effect on fertility and absorption of iron in the blood (Marshall, 1986; Zhao et al., 2014). Vitamin $\mathrm{K}$ is very essential for its help in blood clothing (Kurosu and Begari, 2010; Alagbe et al., 2020).

\section{Amino acid composition of Indigofera tinctoria leaf, stem bark and root}

Table 3 reveals the amino acid composition of Indigofera tinctoria leaf, stem bark and root. The test material contained threonine $(7.65 \%, 1.22 \%$ and $3.03 \%)$, leucine $(5.76 \%, 1.09 \%$ and $2.46 \%)$, lysine $(3.11 \%$, $1.21 \%$ and $2.00 \%)$, valine $(7.21 \%, 3.53 \%$ and $4.09 \%)$, tryptophan $(1.45 \%, 0.03 \%$ and $1.00 \%)$, glycine $(4.76$ $\%, 0.08 \%$ and $2.33 \%)$, phenylalanine $(6.33 \%, 2.45 \%$ and $3.49 \%)$, histidine $(7.42 \%, 2.00 \%$ and $3.00 \%)$, 
methionine $(3.94 \%, 0.01 \%$ and $2.00 \%)$, alanine $(2.41 \%, 0.56 \%$ and $1.20 \%)$, serine $(5.23 \%, 1.22 \%$ and 1.76 $\%)$, aspartic acid $(5.32 \%, 2.11 \%$ and $3.56 \%)$, glutamic acid $(9.66 \%, 4.21 \%$ and $5.11 \%)$, tyrosine $(2.45 \%, 0.57$ $\%$ and $1.67 \%$ ) and cysteine $(1.85 \%, 0.81 \%$ and $0.89 \%)$ for Indigofera tinctoria leaf, stem bark and root respectively. The result obtained in this study is lower than values reported for Moringa oleifera and Psidium guajava leaves, stem and roots by Olorunfemi et al. (2013); Essiet et al. (2016) respectively. Amino acid screening revealed that all the parameters follow similar trend (Indigofera tinctoria leaves $>$ stem bark $>$ roots). Amino acids (AA) were traditionally classified as nutritionally essential or nonessential for animal (Guoyao, 2010).

Glycine is necessary for central nervous system and healthy prostate (Mohammad et al., 2017; Wu et al., 2004). Lysine plays a key role in cell division and growth; its deficiency can lead to impaired fatty acid metabolism and defective connective tissues (Elango et al., 2009). Methionine is essential to cartilage and liver health (Chen et al., 2007; Palii et al., 2009). Isoleucine is vital for the regulation of blood sugar and aids to increase the rate of protein synthesis and muscle tissue formation (Elango et al., 2009; Chmurzynska, 2010). Phenylalanine is necessary in gluscose production for the brain, insulin secretion and fat oxidation (Brosnan et al., 2010). Threonine is paramount in muscle tissue production and also contributes to the neurotransmitter balance in the brain (Watford, 2008). Alanine and glutamic acid protects the cardiovascular system as well as supply energy to the cells of the body (Bruhat et al., 2009). Arginine assists to ensure a healthy immune system and release of growth hormones and insulin in human being (Wu et al., 2004; Tan et al., 2009). Aspartic acid is an excitatory brainstem and spinal cord neurotransmitter that increases the chance of postsynaptic membrane depolarization (Deng et al., 2009). Proline and Serine are necessary in collagen synthesis and epinephrine, creatinine, DNA, RNA production (Brosnan et al., 2010; Brasse et al., 2009). Tyrosine serves as a building block for polypeptide and protein synthesis (Wang et al., 2008).

Conclusion

Medicinal plants are a reservoir of biologically active compounds with therapeutic properties. This is because plant phytochemicals or bioactive chemicals (tannins, phenols, terpenoids, flavonoids, saponins, steroids etc.) possess enormous scaffolds that are mimicked in the design of most molecular structured synthetic drugs or even modified further to enhance a drug's biological activity profile. Thus, there has been a renewed interest in investigating natural products because they are relatively cheap, safe and effective.

\section{References}

* Crisan, E.V and Sands, A. (1978). Nutritive Value. Academic Press, New York, pp. 137-168.

* Olayinka, B.U., Ogungbemi, R.F., Abinde, O.O., Lawal, A.R., Abdulrahman, A.A and Etejere, E.O. (2019). Proximate and phytochemical composition of leaf and root of Carpolobia lutea. Journal of Applied Science and Environmental Management. 23 (1): 53-57.

* Alagbe, J.O. (2019). Proximate, mineral and phytochemical analysis of Piliostigma stem bark and roots. International Journal of Biological, Physical and Chemical Studies. 1(1):8-15.

* Okoh-Esene, Rosemary Uchechukwu, Suleiman Jamila Husseini and Thomas, Sunday Asuquo. (2011). Proximate and phytochemical analysis of leaf, stem and root of Eugenia uniflora (Surinam or Pitanga cherry). J. Nat. Prod. Plant Resour. 1 (4):1-4.

* A.O.A.C. (2000). Association of Official Analytical Chemists. Official Methods of Analysis $19^{\text {th }}$ Edition Washington, D.C Pages 69-77.

* Deng D, Yin YL, Chu WY, Yao K, Li TJ, Huang RL, Liu ZQ, Zhang JS,Wu G.(2009). Impaired translation initiation activation and reduced protein synthesis in weaned piglets fed a low-protein diet. $\mathrm{J}$ Nutr Biochem. (20):544-52.

* Olorunfemi Olaofe, Emmanuel Ilesanmi Adeyeye, Stanley Ojugbo. (2013).Comparative study of proximate, amino acids and fatty acids of Moringa oleifera tree. Applied Chemistry. 54 (2013) 1254312554.

* Gupta, S., Prasad, K and Bisht, G. (2014). Macro and micro mineral contents in some Indian medicinal plants. Research Journal of Phytochemistry. 8:168-171.

* Bruhat A, Cherasse Y, Chaveroux C, Maurin AC, Jousse C, Fafournous P. (2009). Amino acids as regulators of gene expression in mammals: molecularmechanisms. Biofactors. (35):249-57.

* Brasse-Lagnel C, Lavoinne A, Husson A. (2009). Control of mammalian gene expressionby amino acids, especially glutamine. FEBS J. (276):1826-44. 
* Alagbe, J.O., Sharma, R., Eunice Abidemi, Ojo., Shittu, M.D and Bello Kamoru. A. (2020). Chemical evaluation of the proximate, minerals, vitamins and phytochemical analysis of Daniellia oliveri stem bark. International Journal of Biological, Physical and Chemical Stuidies. 2(1): 16-22.

* Soetan, K., Olaiya, C and Oyewole, O. (2010). The importance of mineral elements for humans, domestic animals and plants - A review. African Journal of Food Science. 4: 200-222.

* Princewill-Ogbonna, Ogbonna, PC, Ogujiofor, I.B. (2019). Proximate Composition, Vitamin, Mineral and biologically Active Compounds Levels in Leaves of Mangifera indica (Mango), Persea americana (Avocado pea), and Annona muricata (Sour sop). J. Appl. Sci. Environ. Manage. 23: (1) 65-74

* National Health and Wellness Club (2002). Smart Nutrition: the essential mineral, vitamin and supplement reference guide. NHWC, Minnetonka, Pp 13-76. www.healthandwellnessclub.com

* Shearer, M.J. and P. Newman. (2014). Recent trends in the metabolism and cell biology ofvitamin K with special reference to vitamin K cycling and MK-4 biosynthesis. J. Lipid Res., 55(3): 345-62.

* Shearer, M.J., X. Fu, and S.L. Booth. (2012). Vitamin K nutrition, metabolism, andrequirements: current concepts and future research. Adv. Nutr., 3(2): 182-95.

\# Jolliffe, D.A., C.J. Griffiths and A.R. Martineau. (2013). Vitamin D in the prevention of acuterespiratory infection: systematic review of clinical studies. J. Steroid Biochem. Mol.Biol., 136: 321-9.

* Muhammad Amir Maqbool, Muhammad Aslam., Waseem Akbar and Zubair Iqbal. (2017). Biological importance of vitamins for human health: A review. Journal of Agriculture and Basic Science. 2(3): 5058.

* Kurosu, M and E. Begari. (2010). Vitamin K2 in electron transport system: are enzymesinvolved in vitamin K2 biosynthesis promising drug targets? Molecules 15(3): 1531-53.

* Ba, A., (2008). Metabolic and structural role of vitamin B1e in nervous tissues. Cell Mol.Neurobiol., 28:923-31

* Lanska, D.J. (2010). Chapter 30: historical aspects of the major neurological vitamin deficiencydisorders: the water-soluble B vitamins. Handbook Clin. Neurol., 95: 445-76.

* Combs, G.F. (2007). Vitamin B3. In: The Vitamins. Academic Press, Waltham, MA.

\# WHFoods. (2017). World's Healthiest Foods. http://whfoods.org/.

* McDowell, L.R., (2000). Vitamins in Animal and Human Nutrition. 2nd Edi. Iowa StateUniversity Press/Ames

* Crider, K.S., L.B. Bailey, R.J. Berry. (2011). Folic acid food fortification - its history, effect,concerns, and future directions. Nutrients 3: 370-84.

* Asensi-Fabado, M.A., and S. Munne'-Bosch. (2010). Vitamins in plants: occurrence,biosynthesis and antioxidant function. Trends Plant Sci., 15(10): 582- 592.

* Hayden, M.R. and S.C. Tyagi. (2004). Homocysteine and reactive oxygen species in metabolicsyndrome, type 2 diabetes mellitus, and atheroscleropathy: the pleiotropic effects offolate supplementation. Nutr. J., 3-4.

* Mata-Granados, J.M., R. Cuenca-Acevedo, M.D. Luque de Castro, et al. (2010). Vitamin Ddeficiency and high serum levels of vitamin A increase the risk of osteoporosis evaluatedby QuantitativeUltrasound Measurements (QUS) in postmenopausal Spanish women.Clin. Biochem., 43(13-14): 1064-1068.

* Youdim, K.A., B. Shukitt-Hale, S. MacKinnon, et al. (2000). Polyphenolics enhance red bloodcell resistance to oxidative stress: in vitro and in vivo. Biochim. Biophys. Acta., 1523(1): 117-22.

* Mata-Granados, J.M., R. Cuenca-Acevedo, M.D. Luque de Castro, et al. (2010). Vitamin Ddeficiency and high serum levels of vitamin A increase the risk of osteoporosis evaluatedby QuantitativeUltrasound Measurements (QUS) in postmenopausal Spanish women.Clin. Biochem., 43(13-14): 1064-1068.

* Alagbe, J.O., Sharma, D and Xing Liu (2019). Effect of aqueous Piliostigma thonningii leaf extracts on the haematological and serum biochemical indices of broiler chicken. Noble International Journal of Agriculture and Food Technology. 1(2): 62-69.

* Faurschou, A., D.M. Beyer, A. Schmedes, et al. (2012). The relation between sunscreen layer thickness and vitamin D production after ultraviolet B exposure: a randomized clinical trial. Br. J. Dermatol., 167: 391-5.

* Belenchia, A.M., A.K. Tosh, L.S. Hillman, et al. (2013). Correcting vitamin D insufficiencyimproves insulin sensitivity in obese adolescents: a randomized controlled trial. Am. J. Clin. Nutr., 97: 774-81.

* Marshall, C.W., (1986). Vitamins and Minerals: Help or Harm? George F. Stickley Company. 
* Zhao, L.R., Y.J. Du, L. Chen, et al. (2014). Quercetin protects against high glucose-induceddamage in bone marrow-derived endothelial progenitor cells. Int. J. Mol. Med., 34(4): 1025-31.

* Essiet, Grace Akanimo, Ogbonna, Onyemaechi John, Udofia, Udeme Uyom, Abe, Pierre Noa and Anele, Emmanuel Ikechi. (2016). Phytochemistry, proximate analysis, mineral and vitamin compositions of Psidium guajava linn in methanol root and leaf extracts. International Journal of Pharmacological Research. 6(5): 174-178.

* Guoyao Wu. (2010). Functional Amino Acids in Growth, Reproduction, and Health, Advances in Nutrition, 1(1):31-37, https://doi.org/10.3945/an.110.1008

* Wu G, Bazer FW, Cudd TA, Meininger CJ, Spencer TE. (2004). Maternal nutrition and fetal development. J Nutr. 134:2169-72.

* Elango R, Ball RO, Pencharz PB. (2009) Amino acid requirements in humans: with a special emphasis on the metabolic availability of amino acids. Amino Acids. 37:19-27

* Chen L, Yin Y, Jobgen WJ, Jobgen SC, Knabe DA, Hu W, Wu G. (2007). In vitro oxidation of essential amino acids by intestinal mucosal cells of growing pigs. Livest Sci. 109:19-23

* Palii SS, Kays CE, Deval C, Bruhat A, Fafournoux P, Kilberg MS. (2009). Specificity of amino acid regulated gene expression: analysis of gene subjected to either complete or single amino acid deprivation. Amino Acids. 37:79-88.

* Chmurzynska A. (2010). Fetal programming: link between early nutrition, DNA methylation, and complex diseases. Nutr Rev. 68:87-98.

* Elango, R., Ball, R.O and Pencharz, P.B. (2009). Amino acid requirements in humans: with a special emphasis on the metabolic availability of amino acids. Amino Acids 37: 19-27.

* Mohammed, Y.M., Shovon, B., Abida, S., Shukanta, B., Ashish, K.S., Shujit, C.P and Asaduz, Z. (2017). Evaluation of amino acid profile of Artocarpus heterophyllus seed and its utilization for development of protein enriched supplementary food. Journal of Noakhali Science and Technology University. 1(1): 77 84.

* Wu G, Jaeger LA, Bazer FW, Rhoads JM.(2004). Arginine deficiency in premature infants: biochemical mechanisms and nutritional implications. J Nutr Biochem. 15:442-51.

* Alagbe, J.O and Omokore, E.A. (2019). Effect of replacing soya bean meal with Indigofera zollingeriana leaf meal on the performance and carcass characteristics of growing rabbits. International Journal of Multidisciplinary Research and Development. 6(5): 74-77.

* Tan B, Yin YL, Liu ZQ, Li XG, Xu HJ, Kong XF, Huang RL, Tang WJ, Shinzato I. (2009). Dietary Larginine supplementation increases muscle gain and reduces body fat mass in growing-finishing pigs. Amino Acids. 37:169-75.

* Brosnan J.T, Brosnan M. E. (2010) Creatine metabolism and the urea cycle. Mol Genet Metab. 100:4952.

* Alagbe, J.O. (2019). Effects of dried Centella asiatica leaf meal as a herbal feed additive on the growth performance, haematology and serum biochemistry of broiler chicken. International Journal of Animal Research. 3(23): 1-12.

* Wang J, Chen L, Li P, Li X, Zhou H, Wang F, Li D, Yin Y, Wu G.(2008). Gene expression is altered in piglet small intestine by weaning and dietary glutamine supplementation. J Nutr. (138):1025-32.

* Watford M. (2008). Glutamine metabolism and function in relation to proline synthesis and the safety of glutamine and proline supplementation. J. Nutr. (138):S2003-2007.

* Ngozi, K.A., Chumaraoke, O., Chima, A.E.E and Jennifer, C.O. (2017). Phytochemical, proximate analysis, vitamin and mineral composition of aqueous extract of Ficus capensis leaves in South Eastern Nigeria. Journal of Applied Pharmaceutical Science. 7(3): 117-122.

* Bruneton, J. (1995). Pharmacognosy, phytochemistry, medicinal plants. Paris: Lavoisier Publishing.

* Uniyal, S.K., Singh, K.N., Jamwal, P. and Lal, B. (2006). Traditional use of medicinal plants among the tribal communities of Chhota Bhangal, Western Himalaya. Journal of Ethnobiology and Ethnomedicine, 2: 14 .

* Upadhyay, R.K. (2011). Plant natural products: Their pharmaceutical potential against disease and drug resistant microbial pathogens. Journal of Pharmacy Research, 4(4): 1179-1185.

* Olafadehan, O.A., Oluwafemi, R.A and Alagbe, J.O (2020). Carcass quality, nutrient retention and caeca 
microbial population of broiler chicks administered Rolfe (Daniellia oliveri) leaf extract as an antibiotic alternative. Journal of Drug Discovery. 14(33):146-154.

* WHO (2010). Protein Quality Evaluation; Report of the Joint FAO / WHO Expert consultation. FAO Food and Nutrition Paper 51 Bethseda Md., USA26-42.

* Olafadehan, O.A., Oluwafemi, R.A and Alagbe, J.O. (2020). Performance, haemato-biochemical parameters of broiler chicks administered Rolfe (Daniellia oliveri) leaf extract as an antibiotic alternative. Advances in Research and Reviews, 2020, 1:4.

* Alagbe, J.O., Sharma, R., Eunice Abidemi Ojo, Shittu, M.D and Bello Kamoru Atanda (2020). Chemical evaluation of the proximate, minerals, vitamins and phytochemical analysis of Daniellia oliveri stem bark. International Journal of Biological, Physical and Chemical Studies, 2(1):16-22.

* Yinusa, I., Ndukwe, I.G and Amupitan, J.O. (2007). Phytochemical and antimicrobial screening of aerial part of Indigofera pulchra. Chem. Class. Journal. CSN Zaria, pp:162.

* Oluwafemi, R.A., Isiaka Olawale and Alagbe, J.O. (2020). Recent trends in the utilization of medicinal plants as growth promoters in poultry nutrition- A review. Research in: Agricultural and Veterinary Sciences. 4(1): 5-11.

* Chandrasekaran, S. (2018). Phytochemical, antibacterial and antoxidant properties of Indigofera tinctoria. Asian Journal of Pharmaceutical and Clinical Research. 11(6): 136-138.

* Shinwari, Z.K, Watanabe, T, Rehman, H and Youshikawa, I. (2006). A pictorial guide to medicinal plant in Pakistan. KNUST, Kohat, Pakistan.

* Esimon, C.O.A, Dikwu, M.U and Muko, K.N. (1999). Antibacterial properties of Indigofera leaves. Fitroterapia. 70:517-520.

* Muhammad, S., Sajjad, H and Choudhary, M.I. (2018). Phytochemistry and pharmacology of Indigofera: A review. Rec. Nat. Prod. 12(1): 1-13.

* Abubakar, M.S., Balogun, E.M., Abdulrahman, A.J., Nok, M.M et al. (2006). Ethnomedical treatment of poisonous snake bites. Journal of Phytochemistry.2(10):1-9.

* Chakrabarti, R.B., Damarla, I., Mullangi, V.I (2006). Insulin sensitizing property of Indigofera zollincerna leaf extract. Journal of Agricultural Research, 2(5): 1-5.

* Prakash, M., Suri, S., Upadhyay, G and Singh, S. (2007). Total phenolic free radical scavenging activities of some medicinal plants. Int.J. Food. Sci. Nutr. 58:1-9.

* Bueno, P.L., Lantvit, J., Pan, I., Ninh, T.N and Kinghorn, H. (2013). Bioactive constituents of Indigofera spicata in chicks. J. Nat. Prod. 76: 1498-1504.

* Onwuka, G.I. (2005). Food analysis and instrumentation; theory and practice. African Journal of Biotechnology, 7(1): 1-5. 